\title{
NILAI-NILAI BUDAYA LOKAL DAN KEKERASAN TERHADAP PEREM PUAN MASA HAMIL-NIFAS DI KABUPATEN DONGGALA SULAWESI TENGAH
}

\author{
Rosmala N ur \\ Universitas M uhammadiyah Palu \\ E-mail: malanur_id@yahoo.com
}

\begin{abstract}
A bstrak: This research is aim to study the local cultural forms which cause the domestic violence, especially on pregnancy woman. The research conducted in countryside of Sunju and Tg Batu, Donggala $M$ iddle Sulawesi district. The sample of the study is entire pregnancy women, and the women who were pregnancy two years ego. The total number of sample is 94 people. Data collecting are interview, focus group discussion, and documentation. The result of the research indicates that the value of local cultural namely siri', naeya, and doi' balanca as the cause of domestic violence, especially violence on pregnancy women
\end{abstract}

Kata Kunci: budaya, kekerasan pada perempuan, hamil

\section{PENDAHULUAN}

Akhir-akhir ini fenomena kekerasan terhadap perempuan menjadi isu sosial nasional. Hal ini disebabkan karena baik jumlah, bentuk dan kualitas kekerasan semakin kompleks dari tahun ke tahun. Selain itu kekerasan terutama selama masa kehamilan dan pasca kehamilan dapat berdampak serius pada kesehatan ibu dan anaknya. ${ }^{1}$ Dalam studinya Heise menemukan sekitar 6 persen sampai 15 persen perempuan telah mengalami tindak kekerasan seksual dan fisik oleh pasangan intim mereka selama hamil dan 38 persen di antara ibu- 
ibu tersebut telah mengalami kekerasan dalam kehidupannya. Sementara itu Curry et al. ${ }^{2}$ mengatakan bahwa di seluruh dunia satu diantara empat perempuan selama kehamilannya mengalami kekerasan fisik dan seksual oleh pasangannya, dengan estimasi yang sangat bervariasi. Sebagai contoh di Amerika Serikat diperkirakan kekerasan terhadap perempuan hamil berkisar antara 3 persen sampai 11 persen dan di antara para remaja lebih dari 33 persen.

Gazmararian et al. ${ }^{3}$ mengemukakan bahwa dari hasil sebelas studi prevalensi kekerasan selama hamil di beberapa negara (Boston, Texas, Virginia, Baltimore, Amerika, Toronto dan Australia) hampir 156.000 sampai 332.000 ibu telah mengalami kekerasan selama hamil. Wacana ini menunjukkan bahwa kekerasan selama hamil memang ada dan terjadi di belahan dunia. Begitu pula di Indonesia. Prevalensi kekerasan terhadap ibu hamil untuk kondisi di Indonesia dapat dilihat pada Tabel 1.

\section{Tabel 1}

Prevalensi Kekerasan Terhadap Ibu Hamil di Indonesia

\begin{tabular}{|c|c|c|c|c|c|}
\hline No & $\begin{array}{l}\text { Peneliti/ } \\
\text { Lembaga }\end{array}$ & $\begin{array}{l}\text { Tempat/ } \\
\text { Kabupaten }\end{array}$ & $\begin{array}{l}\text { Bentuk } \\
\text { Kekerasan }\end{array}$ & $\begin{array}{l}\text { Prevalensi } \\
\text { Selama } \\
\text { Hamil }\end{array}$ & $\begin{array}{l}\text { Kekerasan } \\
\text { Berganda } \\
\text { Sel ama H amil }\end{array}$ \\
\hline 1 & $\begin{array}{l}\text { Hakimi } \\
\text { dkk. (2001) }\end{array}$ & Purworejo & $\begin{array}{l}\text { Fisik, } \\
\text { emosional } \\
\& \text { seksual }\end{array}$ & $\begin{array}{l}18 \% \text { ibu } \\
\text { hamil dari } 725 \\
\text { perempuan } \\
\text { responden }\end{array}$ & $\begin{array}{l}4 \text { persen dari } \\
18 \%\end{array}$ \\
\hline 2 & $\begin{array}{l}\text { Ni Komang } \\
\text { (2004) }\end{array}$ & $\begin{array}{l}\text { Bandung dan } \\
\text { Bali }\end{array}$ & $\begin{array}{l}\text { Fisik, } \\
\text { emosional } \\
\& \text { seksual }\end{array}$ & $\begin{array}{l}85,7 \% \\
\text { dari } 105 \mathrm{ibu}\end{array}$ & $\begin{array}{l}26,6 \% \text { dari } 85,7 \\
\text { persen }\end{array}$ \\
\hline 3 & $\begin{array}{l}\text { Komnas } \\
\text { Perempuan } \\
\text { Indonesia } \\
\text { (2005) }\end{array}$ & $\begin{array}{l}\text { Data } \\
\text { dihimpun } \\
\text { dari } 11 \\
\text { Rumah Sakit } \\
\text { dari } 9 \\
\text { provinsi, } 28 \\
\text { RPK, } 43 \text { LSM } \\
\text { dan } 20 \\
\text { Pengadilan } \\
\text { Negeri }\end{array}$ & - & $\begin{array}{l}\text { hamil } \\
9,49 \% \text { ibu } \\
\text { hamil } \\
\text { dari } 6.630 \\
\text { orang } \\
\text { perempuan } \\
\text { yang } \\
\text { melaporkan } \\
\text { sebagai } \\
\text { korban }\end{array}$ & - \\
\hline
\end{tabular}

Sumber : Diperoleh dari Berbagai D ata Penelitian

Di Sulawesi Tengah, berdasarkan data dari Kantor Polda Sulawesi Tengah selama periode tahun 2002-2004 menunjukkan tindak kekerasan terhadap perempuan tertinggi di Kota Palu sebanyak 86 kasus dan Kabupaten Donggala 78 kasus, sedangkan kabupaten lainnya antara 50-65 kasus. Untuk 
Kabupaten Donggala pada periode tahun 2005 - 2006 meningkat menjadi 80 kasus (Humas Polda Sulteng, Desember 2006).

Prevalensi kekerasan pada ibu hamil yang dihimpun dari Rumah Sakit Umum Donggala, menunjukkan bahwa pada tahun 2004-2005 sebanyak 14 kasus dan pada tahun 2006-2007 meningkat tajam menjadi 27 kasus. Diperkirakan, masih banyak lagi jumlah yang tidak terdeteksi karena tidak semua bidan/ petugas kesehatan utamanya di desa, mengetahui skrining awal kekerasan terhadap ibu hamil serta konsep kekerasan yang dipahami masih merujuk pada kekerasan fisik semata (Ka. Bagian KIA RSU Donggala, 2007).

\section{Tabel 2}

Perkembangan Jumlah Kasus Kekerasan terhadap Perempuan dan Ibu Hamil di Kabupaten Donggala

\begin{tabular}{cccc}
\hline Periode & $\begin{array}{c}\text { Kekerasan terhadap } \\
\text { Perempuan }\end{array}$ & Periode & $\begin{array}{c}\text { Kekerasan } \\
\text { terhadap } \\
\text { Ibu Hamil }\end{array}$ \\
\hline $2002-2004$ & 78 & $2004-2005$ & 14 \\
$2005-2006$ & 80 & $2006-2007$ & 27 \\
\hline
\end{tabular}

Sumber : Polda Sulteng dan D inas Kesehatan D onggala

Rangkaian data di atas memberi makna bahwa perempuan karena kehamilannya telah mengalami penganiayaan atau kekerasan. Fenomena ini mengundang pertanyaan mendasar, "mengapa perempuan pada masa hamil mendapatkan kekerasan?". A pakah terdapat nilai-nilai budaya lokal sebagai determinasi terjadinya kekerasan pada ibu hamil-nifas tersebut?. Penelitian ini mengkaji pengaruh faktor-faktor budaya masyarakat terhadap terjadinya kekerasan suami terhadap istri pada masa hamil-nifas di Kabupaten Donggala Sulawesi Tengah.

\section{METODE PENELITIAN}

Penelitian dilakukan di Desa Sunju (perdesaan) dan Kelurahan Tanjung Batu (perkotaan) Kabupaten Donggala Sulawesi Tengah. Sampel penelitian ini adalah seluruh perempuan kawin usia subur yang sedang hamil, masa nifas, pernah mengalami hamil dan melahirkan maksimum 2 tahun lalu, dan mengalami kekerasan pada masa itu sebanyak 94 responden. Pengumpulan data dilakukan melalui wawancara, focus group discussion dan dokumentasi.

\section{HASIL PENELITIAN}

\section{Budaya Siri', Naeya}

Perilaku individu dalam keluarga termasuk kekerasan suami terhadap istri masa hamil-nifas tidak dapat terlepas dari adanya norma sosial dan agama yang membolehkan perilaku laki-laki mengontrol perempuan dalam setting 
makro. Di Tanjung Batu terdapat budaya siri', di Sunju disebut budaya naeya atau penjagaan rasa malu. Perempuan dipandang sebagai simbol siri', naeya keluarga. Akibatnya perempuan diatur, dipantau secara ketat oleh anggota keluarga bahkan oleh masyarakat sekitar yang lebih tepat disebut sebagai tomasiri' (orang yang bertanggung jawab menjaga siri' keluarga). ${ }^{4}$ Oleh karena perempuan sebagai simbol siri' keluarga, maka perempuan harus selalu di bawah kontrol laki-laki. Budaya semacam ini oleh Foucault ${ }^{5}$ dibahasakan sebagai "aturan simbolis" di mana perempuan diatur oleh serangkaian tanda (simbol). Tanda ini diinternalisasikan sejak kecil melalui bahasa maskulin dan masuk dalam alam bawah sadar masyarakat maupun perempuan itu sendiri sehingga telah membudaya.

Bukti nyata aturan simbolis yang dikomunikasikan lewat bahasa maskulin di lokasi penelitian seperti dalam ungkapan "lakkaingnnu tu tau matowanu" (suamimu adalah orang tuamu). Artinya seorang perempuan yang telah kawin harus mengikuti suaminya dengan setia, karena suami ibarat orangtuanya. Nilai simbolik tersebut membentuk "common-sense" perempuan maupun laki-laki bahwa apabila mereka telah menikah, perempuan menjadi milik suaminya. Konsep maskulinitas diadopsi dalam simbolisme kehidupan keluarga dan yang terjadi adalah dominasi suami atas istri. Pada tataran inilah tindak kekerasan terhadap istri banyak terjadi seperti pengakuan Ibu Up,30 tahun, di Sunju sebagai berikut.
Aiii, susah bu...apa' dia itu biar kita keluar rumah sedikit saja, kita harus minta izin. Saya ditempeleng itu karena waktu itu dia lagi di sawah, trus ada pemberitahuan dari ibu Upik (Kader Posyandu) bahwa sebentar ada acara di Posyandu. Karena ada tamu kata dari Kabupaten. Jadi semua ibu-ibu hamil, dan yang punya bayi diundang. Tapi paitua pulang ke rumah shalat duhur. Eh, dia te' dapati saya di rumah. Disangkami saya pergi macam- macam..Padahal saya so kasih jelaskan. Disitumi dia tempeleng saya bu...Dia bilang, „saya ini penguasa di rumah ini“, kalo ada apa-apa bilang sama saya“. Bagaimana mau dibilang, kong dia ada di sawah bu.

Simbolis lain dalam bahasa maskulin nampak dari istilah "ma'jaga siri' yang berarti bahwa kehormatan suami harus dilindungi dari orang-orang di luar keluarganya. Demi menjaga siri' keluarga, peristiwa yang terjadi pada istri seyogyanya dibungkus rapat-rapat. Seperti penuturan Ibu A.En, 29 tahun di Tanjung Batu.

M asiri'ka bu...(malu saya bu) pergi melapor atau ba' kasi h tau orang soalnya ini khan siri' keluarga. Kalo saya pigi melapor itu berarti saya tempeleng muka saya sendiri, ini khan aib sendiri, biarlah dulu begitu, suatu saat juga paitua akan berubah. 
Apa yang diutarakan oleh Ibu Up dan Ibu A.En menunjukkan bahwa betapa konsep maskulinitas sebagai produk budaya siri' diterjemahkan dalam relasi suami istri dan keluarga. Hal ini juga merepresentasekan istri sebagai korban telah masuk dan menerima apa yang disebut aturan bapak (law of the father). ${ }^{6}$ Pusat kekuasaan di tangan laki-laki. Ketimpangan relasi kuasa laki-laki dan perempuan inilah yang melahirkan kekerasan fisik dan psikologis masa hamil. Temuan ini meneguhkan teori nurture ${ }^{7}$ yang melihat kekerasan dapat terjadi pada perempuan karena hasil konstruksi budaya dan masyarakat yang menempatkan laki-laki lebih unggul dari perempuan. Demikian pula penemuan Khairuddin (1998) ${ }^{8}$ memperlihatkan bahwa kultur yang patriarkhi dalam etnis tertentu seperti di Jayapura merupakan penyebab terjadinya kekerasan suami terhadap istri.

Agak menarik ketika budaya siri' dipotret pada komunitas berbeda. Di kota, siri' dan kekerasan lebih mengejawantah daripada di desa. Manifestasi perbedaan tersebut nampak pada bentuk dan kualitas kekerasan yang dilakukan suami. Berikut data kualitatif mendukung pandangan ini. Puang Syahrir, 41 tahun di Tanjung batu mengungkapkan sebagai berikut.

Saya tempeleng dia (istri saya) karena saya selalu dilawan. Kalau kita orang Bugis di patua-tuai (dilecehkan) sama istri itu khan siri'...harga diri. Harga diri harus dibalas dengan tempeleng, bahkan saya bunuh istri saya tidak apa-apa....itu bagian dari harga diri laki-laki...

Hal senada oleh Bapak Udin, 37 tahun di Tanjung Batu, mengungkapkan sebagai berikut.

Saya seringkali marah besar terhadap istri saya, karena saya sebagai laki-laki telah diinjak-injak harga diri saya sebagai laki-laki. Saya sebagai suami tidak boleh dibantah...di lawan...karena disitu mi...harga seorang laki-laki..A palagi kalau perempuan mau potepote (ngomelin) saya.tunggu...mi melayang mi tu pajjaguru (tinju).

Sedikit berbeda dengan ungkapan di atas, manifestasi naeya dan kekerasan datang dari Bapak Rs penduduk asli Desa Sunju.

Meskipun saya dongkol sekali sama maitua, tapi tidak pernah saya ba' tempeleng atau ba'tinju kasian. Ya memang naeya, tapi khan tidak sampai kesitu artinya. Ini pendapat saya khan. Saya akui saya selau gertak saja, ya kata-kata kasar, tidak apa-apa khan, wajar istri sayajuga. 
Dari ketiga ungkapan di atas nampak bahwa terdapat perbedaan refleksi kekerasan yang dilahirkan nilai-nilai siri' dan naeya. Suami yang di kota pada kasus tersebut cenderung lebih keras menterjemahkan siri' ketimbang suami di desa. Temuan ini sebenarnya temuan baru karena berlawanan dengan pernyataan dan penemuan sebelumnya seperti La Side (1977) ${ }^{9}$, Tantowi (2007) yang menuliskan bahwa di desa penjagaan dan apresiasi terhadap siri' lebih kental ketimbang di kota sehingga nilai-nilai budaya siri' lebih dominan berpengaruh di desa ketimbang di kota. Terjadinya perbedaan ini dimungkinkan karena siri' memang budaya asli etnis Bugis. Terdapat kecenderungan di manapun keberadaannya nilai-nilai siri' bagi orang Bugis tetap menjadi pegangannya. ${ }^{10}$ Produksi, reproduksi, dan apresiasi terhadap nilai-nilai siri' lebih kental, intens dan lebih terasa di Kota Tanjung Batu. Berbeda dengan naeya di Sunju. Nilai tersebut kemungkinan hanya terkulturasi dari penduduk mayoritas Donggala sehingga persepsi terhadap konsep naeya sebagai harga diri juga berbeda. Perbedaan ini melahirkan bentuk dan kualitas kekerasan yang berbeda.

Konspirasi phallus yang mengeras dalam budaya siri', naeya tersebut juga diperkuat dengan nilai-nilai agama yang mereproduksi terjadinya kekerasan berbasis gender. A shari ${ }^{11}$ mengungkapkan bahwa apapun yang ditekstualkan oleh kitab suci secara otomatis harus menjadi kewajiban untuk diikuti. Selain itu terjadinya bias gender dalam memahami agama adalah penafsiran keliru terhadap teks ayat. Dalam Alkitab, dicontohkan oleh Sientje M erentek Abram bahwa pewahyuan itu diberikan dalam proses waktu yang panjang, melalui banyak orang yang berbeda watak, gaya serta mempunyai latar belakang keahlian yang berbeda. Konsekuensinya maka penyampaian Alkitab itu jelas begitu kaya dan beragam. Begitu pula dalam Islam, misalnya penyampaian hadits-hadits. Oleh karena dituturkan dalam kondisi yang berbeda maka tentu pemaknaannya pun berbeda, bahkan tidak sedikit palsu, yang dalam kaitannya dengan perspektif perempuan akan merusak pencitraan terhadap perempuan.

Beberapa konsep ajaran Islam yang dipahami masyarakat Sunju dan Tanjung Batu menjadi turut pelanggeng kekerasan terhadap perempuan adalah konsep cerai dan poligami. Cerai merupakan hak mutlak suami yang dapat dilakukan sesuai kehendaknya kapanpun dan di manapun. Posisi ini tentunya menjadikan hidup perempuan dalam ancaman bayang-bayang perceraian, sementara poligami merupakan pembuka ruang terjadinya kekerasan terhadap istri menjadi istri kedua, ketiga, atau hidup dimadu. Penuturan Bapak Ramli, 51 tahun, di Desa Sunju yang memiliki dua orang istri sebagai berikut.

Kawin beberapa kali khan tidak dilarang oleh agama, cerai juga halal, apa yang salah saya lakukan. Saya cuma menjalankan perintah agama kok. Jadi poligami itu halal dan tidak berdosa. 
Selain hal di atas, ajaran agama yang turut melanggengkan kekerasan adalah konsep muhrim. Kejadian ini di alami oleh Ibu Wd, 31 tahun di Sunju yang selalu dilarang oleh suaminya untuk bersolek atau memakai pakaian sesuai keinginannya. Padahal ia memiliki hobbi dalam bidang tata rias. Ibu Wd sebelum menikah bekerja sebagai perias pengantin. Setelah menikah, ia dilarang oleh suaminya untuk meneruskan profesi tersebut. Bahkan Ibu Wd sekarang ini dalam aktifitas tertentu telah dibatasi keluar rumah. Walaupun dari pengakuannya bahwa ia tak pernah dipukul, tetapi ia merasa batinnya sangat menderita menjalani kehidupan rumah tangganya karena kebebasan untuk berekspresi dihambat ol eh suami. Kini ia nampak sangat kurus dan lebih tua dari umurnya. Setelah dikonfirmasi kepada suaminya, maka dengan lantang Bapak Edi, 41 tahun menjelaskan seperti di bawah ini.

Perempuan harus tinggal di rumah mengacu pada AI Qur'an surat Al-Ahzab ayat 33 yang artinya ...“dan hendaklah kamu tetap di rumahmu dan janganlah kamu berhias dan bertingkah laku seperti orang-orang jahiliyah yang dahulu........ “. sesungguhnya Allah bermaksud hendak menghilangkan dosa dari kamu, hai ahlal bait dan membersihkan kamu sebersih-bersihnya.

Kalo ayat ini dilanggar, saya sebagai imam akan ditanyai oleh Allah SWT, tentang pertanggungjawaban ini kepada keluarga saya. Jadi yang saya lakukan ini, adalah agar istri saya masuk syurga..

Cuplikan beberapa pandangan di atas, menjadi bukti kuat bahwa ajaran agama turut memproduksi kekerasan. Terjadinya tindak kekerasan terhadap perempuan dalam sistem religi adalah karena penafsiran yang keliru terhadap teks kitab suci. Kesimpulan ini oleh Suratno (2006) disebut penafsiran hermeneutis. Artinya, setiap penafsiran terhadap teks secara otomatis melibatkan berbagai kepentingan, motivasi serta tendensi untuk menerima atau menolak jenis-jenis kekuasaan tertentu. Agama dan kitab suci bukanlah suatu yang selalu independen, melainkan dependen pada person dan kultur yang ada di sekitarnya. Independensi agama dan kitab suci dapat diukur seberapa jauh dapat menjalankan fungsi kritisnya dalam masyarakat. Dalam fakta di atas agama dan kitab suci kecenderungannyamenempatkan perempuan dalam posisi memprihatinkan. Dalam kaitan ini agama menjadi entry point pelanggengan kekerasan terhadap perempuan hamil-nifas baik di Desa Sunju maupun di Tanjung Batu. Temuan tersebut relevan dengan kajian Ridwan (2006) dan Umar (2004) yang memperlihatkan bahwa nilai-nilai agama yang dianut masyarakat turut mempengaruhi terjadinya kekerasan terhadap istri.

Meskipun nilai-nilai agama mempengaruhi lahirnya kekerasan namun terdapat perbedaan di kota dan di desa, refleksi terhadap ajaran agama agaknya lebih kental di desa ketimbang di kota. Di desa, ditemui ajaran agama yang sangat ekstrim di mana perempuan hamil tidak boleh ditangani oleh petugas kesehatan laki-laki. Pengalaman ini diungkapkan oleh ibu Mn bahwa 
ia tak pernah diantar suaminya ke dokter (kekerasan psikologis) karena takut dosa. Ajaran itu diadopsi oleh suaminya dari seorang ustadz yang cukup disegani di Kecamatan Marawola dalam suatu ceramahnya mengemukakan seperti berikut ini.

...telah banyak perbuatan dosa di sekitar kita yang kadang kita biarkan. Seperti istri yang mau melahirkan, kita antar ke Puskesmas atau rumah sakit. Di sana yang layani petugas laki-laki. Dengan bebasnya si petugas ini melihat alat kelamin istri kita. Bahkan lebih dari itu si dokter ini memasukkan tangannya pada alat kelamin istri kita dengan dalih memeriksa, so pembukaan ke berapa?...1,2,3 dan seterusnya, A pa artinya ini? Ini adal ah kebathilan yang dibiarkan.

Di kota, meskipun ajaran itu ada, tetapi sebagian suami masih melakukan reinterpretasi terhadap ajaran tersebut dan tetap mengantar istrinya ke dokter laki-laki. Pengakuan Bapak Hs 47 tahun, bahwa kelahiran anaknya semua ditangani dokter laki-laki. Ia tak menampik bahwa terdapat ajaran yang melarang istri ditangani dokter laki-laki dengan alasan bukan muhrim. Namun ia juga berpandangan lain bahwa „agama tidak sesempit itu“. Wacana ini menunjukkan bahwa meskipun prediktornya sama namun karena perbedaan wawasan, pendidikan dan komunitas menyebabkan perilaku suami berbeda. Dengan demikian dapat disimpulkan bahwa kekerasan terhadap istri masa hamil-nifas disebabkan nilai-nilai budaya dan agama. Kuat dan lemahnya pengaruh tersebut terkait dengan faktor lain seperti tingkat pendidikan serta tempat tinggal. Kesimpulan ini memperteguh teori Heise ${ }^{12}$ bahwa nilai dan norma yang berlaku dalam masyarakat yang saling berinteraksi pada level lain sebagai pemicu terjadinya kekerasan pada istri.

\section{Budaya Uang Perkawinan/D oi' Balanca}

Dalam adat perkawinan Bugis dan Kaili terdapat dua syarat yang harus dibawa laki-laki apabila ingin melangsungkan perkawinan yaitu mahar dan uang perkawinan (doi' balanca, sunda). Mahar perkawinan umumnya dari barang tak bergerak seperti tanah, sawah, rumah, kebun, pohon kelapa dan sebagainya. Mahar perkawinan dalam Hukum Islam memang wajib hukumnya untuk sah tidaknya perkawinan. Dalam proses ijab kabul, bentuk mahar disebut oleh pihak calon mempelai laki-laki di hadapan penghulu. Berbeda dengan uang perkawinan atau doi balanca (Bugis), sunda (Kaili) tidak wajib hukumnya dalam Hukum Islam, namun dalam adat Bugis dan Kaili sama kedudukannya dengan mahar. Uang perkawinan dipandang hal yang penting dalam perkawinan dan penentu jadi tidaknya suatu perkawinan.

Penentuan besar kecilnya jumlah uang dan mahar perkawinan yang dibawa cal on mempelai laki-laki sangat bergantung pada hasil musyawarah keluarga pihak calon suami-istri. Data FGD (2007) diperoleh bahwa tinggi rendahnya status sosial-ekonomi keluarga wanita yang hendak dikawininya 
juga sangat menentukan besar kecilnya uang perkawinan. Status tersebut biasanya diukur dengan keperawanan (originalitas), tingkat pendidikan, status pekerjaan, agama, dan perilaku serta kecantikannya. Seorang tokoh masyarakat Tanjung Batu, Bapak Helmi, 54 tahun menyatakan sebagai berikut.

Bila seorang perempuan mau kawin dengan status sosial yang tinggi (perempuannya perawan, sudah bekerja PNS, sarjana, agamanya baik serta wajah cukup lumayan, maka uang perkawinannya untuk kondisi sekarang paling rendah 30 juta. Tapi kalau tidak ada kerjanya...tamatan SMA saja...ya cuma 10 - 20 juta saja.

Oleh karena uang perkawinan sangat terkait dengan keperawanan maka jumlahnya juga sangat terkait dengan latar belakang perkawinan (kawin secara adat atau kawin kecelakaan). Kawin secara adat lebih tinggi uang perkawinannya ketimbang kawin kecelakaan (kawin lari, hamil dulu baru nikah dan kawin karena tertangkap basah oleh tokoh adat). Gambaran jumlah uang perkawinan serta maskawin yang dihimpun peneliti selama di lapangan tertera pada Tabel 3.

Teknis pembayaran uang perkawinan berkaitan pula dengan latar belakang perkawinan. Kawin secara adat, pembayaran uang perkawinan dilakukan secara tunai dalam sebuah pesta besar. Seluruh keluarga dan kerabat diundang untuk menyaksikan pembayaran uang perkawinan tersebut. Di Kota Tanjung Batu disebut mappaenre doi balanca, di Sunju di sebut sunda (pesta penerimaan hantaran uang perkawinan).

\section{Tabel 3}

Uang dan Mahar Perkawinan Yang Ditentukan Menurut Adat Istiadat Penduduk Sunju dan Tanjung Batu Juli 2007-Juli 2008

\begin{tabular}{lllllc}
\hline $\begin{array}{c}\text { N } \\
\text { 0. }\end{array}$ & $\begin{array}{c}\text { Desa/ } \\
\text { kelurahan }\end{array}$ & \multicolumn{1}{c}{$\begin{array}{c}\text { Status } \\
\text { Perkawinan }\end{array}$} & $\begin{array}{c}\text { Tingkat } \\
\text { Pendidikan }\end{array}$ & $\begin{array}{c}\text { Uang } \\
\text { Perkawinan }\end{array}$ & $\begin{array}{c}\text { Sunrang/ } \\
\text { Mahar } \\
\text { Perkawin } \\
\text { an }\end{array}$ \\
\hline 1 & Sunju & Magello/ Nabelo* & SMP & Rp.10.000.000 & Tanah \\
2 & Sunju & Magello/ Nabelo & SMA & Rp.12.500.000 & Tanah \\
3 & Sunju & Magello/ Nabelo & SMP & Rp.10.000.000 & Tanah \\
4 & Sunju & Silariang & SMA & Rp. 3.000.000 & Emas \\
5 & Tanjung Batu & Magello/ Nabelo & SMA & Rp.15.000.000 & Tanah \\
6 & Tanjung Batu & Magello/ Nabelo & SMA & Rp.25.000.000 & Tanah \\
7 & Tanjung Batu & Magello/ Nabelo & SMA & Rp.20.000.000 & Tanah \\
8 & Tanjung Batu & Silariang/ hamil & SMA & Rp.3.500.000 & Pohon \\
& Sebelum nikah & & & kelapa \\
9 & Tanjung Batu & Silariang & SMA & Rp.5.000.000 & Pohon \\
& & & & kelapa \\
\hline
\end{tabular}

Sumber : Diolah dari data lapangan 
Bagi perempuan yang kawin kecelakaan teknis pembayarannya dilakukan secara diam-diam dan tertutup. Oleh karena sifatnya tertutup memungkinkan masih adanya diskon serta dapat diangsur atau utang. Kalau saja dibayar secara angsuran dan diutang tetapi tidak lancar pembayarannya, penagihan akan terus terjadi dari pihak keluarga wanita (istri). Pada gilirannya, istrilah dan anak-anak kadang-kadang menjadi sasaran kemarahan suami. Sebagai ilustrasi, berikut disajikan cuplikan hasil wawancara dengan Ibu $\mathrm{CH}$, 27 tahun di Sunju.

A walnya...saya pacaran biasa ji dengan paitua. Tapi lama kelamaan tambah mendalam. Suatu ketika saya diajak nonton acara dero malam-malam, dan ketika mati listrik, maka terjadilah itu.... Akhirnya saya hamil, dan sejak saat itu pacar saya marah terus. Singkat cerita saya dinikahkan oleh paman saya khan...saya pikir paitua mau berubah, ternyata belum berubah... dan sampai sekarang masih sering menendang perut saya, karena hamil ini dia te' suka.... Paling sakit hati saya bu...kalo saya ini tidak apa-apa lalu dipukul, katanya dia te' suka ditagih-tagih uang perkawinan dan segala macamnya. Itu risikonya kalo hamil duluan. Saya juga dibilangi wanita murahan. Karena waktu kawin cuma 3 juta uang naik, itupun belum dibayar khan. Saya belum balik untuk maddeceng (baku baek sama orang tua).

Tampak begitu jelas dari cuplikan di atas bahwa uang perkawinan yang murah dan belum lunas menjadi salah satu penyebab timbulnya kekerasan terhadap istri. Ada kecenderungan yang cukup besar pula untuk memperlakukan istri seperti apa yang dimauinya. Cara pandang demikian ini sebagai bentuk komodifikasi terhadap perempuan. Komodifikasi terhadap perempuan yang dibungkus nilai-nilai budaya melahirkan ide ownership terhadap perempuan. Ide kepemilikan yang tinggi menyebabkan ketimpangan gender dan perempuan rentan dengan kekerasan. Penemuan ini konsisten dengan kajian Khairuddin ${ }^{13}$ bahwa mahar perkawinan yang dicicil dan dikontan pada suku di Jayapura menyebabkan perbedaan kekerasan. Istri yang dibayar mas kawinnya secara kontan lebih rentan terhadap kekerasan ketimbang yang dicicil. Suami menganggap bahwa mas kawin yang lunas, ia memiliki otoritas tubuh terhadap istrinya. Demikian pula Fakih (2001) bahwa perkawinan pada etnis berbeda yang menganut sistem perkawinan "jual-beli" merupakan bentuk relasi-eksploitasi sebagai produk patriarkhi. Bentuk relasi semacam ini menyebabkan perempuan rentan terhadap kekerasan.

Nampaknya problema uang kawin ini lebih tinggi di kota (7,1 persen) ketimbang di desa (2,9 persen). Kasusnya pun lebih dominan pada istri yang dibayar mahal. Oleh karena mahalnya uang kawin yang dibayarkan pada saat 
perkawinan, membuat orang tua pihak suami berutang kepada orang lain. Bilamana orang tua tidak sanggup membayar utang perkawinan anaknya, seringkali pihak anak yang telah dikawinkan tersebut turut dibebaninya. Menariknya adalah bahwa persoalan utang kawin muncul ke permukaan jika suami telah mengetahui istrinya telah hamil. Artinya perilaku suami yang meminjam uang pada pihak luar terkadang diberitahukan kepada istri jika istri dalam keadaan hamil. Asumsinya adalah jika istri telah hamil, apapun yang dilakukan suami, istri akan pasrah menerimanya termasuk melunasi utang kawin walau dilakukan secara kredit. Kemungkinan sebagian istri akan menerima secara pasrah karena mereka sudah terlanjur hamil, namun sebagian istri seringkali tidak menerima perlakuan tersebut dan inilah pemicu terjadinya kekerasan. Pengakuan seorang istri Ibu Wd, 22 tahun di Tanjung Batu.

Saya memang bertengkar paitua bu...tapi ini khan rahasia, mertua saya tidak boleh tahu ini.. masa' paitua berutang di koperasi hanya karena mau membayar utang kawin dulu...alasannya kata orang tuanya masih berutang...ya menurutku itu khan urusan orang tuanya khan, masa' kami turut menanggung bu.., kenapa sanggupi dulu kalo tidak mampu bayar...kita juga sebenarnya malu bu... sudah mau punya anak (hamil), kita masih ba'utang uang kawin...

Pengakuan serupa oleh Ibu Een, 24 tahun bahwa ia telah mengandung anak yang kedua, namun belum lunas utang kawinnya.

Sampai kapan saya sabar bu..kita khan juga butuh untuk membangun rumah, beli motor, butuh biaya anaknya tapi kita masih ba'cicil uang kawin..Sknya digadaikan di bank. Jadi gajinya te cukup untuk kita... mungkin nanti lunas pi itu bu...baru baik-baik saya punya rumah tangga kasian..

A pa yang dituturkan oleh beberapa korban di atas memiliki pengalaman dan pandangan yang sama bahwa uang kawin penyebab kekerasan pada masa hamil-nifas. Keharusan membawa uang kawin yang mahal tidak didukung oleh kondisi ekonomi yang memadai, membuat sebagian orangtua berutang kepada pihak keluarga lain dan setelah menikah acapkali mereka yang turut menanggungnya.

Di desa, meskipun uang kawin terkait dengan kekerasan, namun kasusnya hanya satu. Hal tersebut menunjukkan bahwa determinasi uang kawin di kota jauh lebih ketat ketimbang di desa. Gejala ini cukup beralasan karena budaya "uang kawin" lebih melekat pada budaya etnis Bugis ketimbang pada etnis Kaili di desa. Perbedaan ini memperkuat analisis Raharjo (2008) bahwa perbedaan lingkungan geografis setempat serta kebiasaan yang berlangsung lama dalam komunitasnya sehingga menjadi karakter komunitasnya menyebabkan perilaku seseorang berbeda. 
Masyarakat perlu menyadari dan memberi perhatian yang serius akan dampak yang ditimbulkan oleh uang kawin tersebut. Saat ini diperlukan suatu perubahan pemikiran untuk melihat perkawinan dalam konteks kebutuhan kedua pasangan (sunnah Rasul) untuk berkomitmen membentuk rumah tangga. Perkawinan tidak dipandang dalam konteks "jual beli", namun lebih ke substansi tujuan perkawinan itu sendiri. Dengan demikian pembayaran uang perkawinan tidak lagi menghambat terjadinya suatu perkawinan sekaligus diharapkan akan mengurangi risiko terjadinya kekerasan dalam rumah tangga. Merubah cara pandang masyarakat seperti ini, apalagi terkait dengan adat istiadat memang cukup sulit walaupun itu harus dilakukan.

\section{Simpulan}

Sesungguhnya episentrum terjadinya kekerasan pada masa hamil-nifas adalah dominasi laki-laki terhadap perempuan. Bentuk ekspresif rasa dominasi terwujud melalui nilai-nilai budaya dan agama yang membolehkan laki-laki mengontrol perempuan. Nilai-nilai budaya tersebut yakni budaya siri', naeya serta uang perkawinan/ doi' balanca merupakan prediktor yang mempengaruhi munculnya kekerasan suami terhadap istri pada masa hamil-nifas.

\section{Endnotes:}

1 Heise L. 1998. “Violence A gainst Women, an Integrated Ecological Framework in Stanley G. French, Wanda Teays dan Laura M.Purdy (eds), Violence Against Women; Philosophical Perspective Ithaca: Cornell University Press. p. 10

2 Cury, MA., Perrin N and Wall E., 1998. Effects of Abuse on Maternal Complications and Birth Weight in Adult and Adolescent Women. International Journal of Obstertics and Gynecology, Vol. 92 Pp 530-534

3 Gazmararian, J.A., Lazorick, S., Splitz, A.M., Ballard, T.J., Saltzman, L.E., \& Marks, J.S., 1996. Prevalence of Violence against Pregnant Women, Journal of American M edical A ssociation, 275, 1915 - 1920. p. 1917

4 Rahim, Rahman., 1985. Nilai-Nilai U tama Kebudayaan Bugis. Ujung Pandang: Lembaga Penelitian Universitas Hasanuddin.

5 Foucault, Michel., 1980. Power/Knowledge: Selected Interview \& O ther W riting 1972-1977, Colin Gordon (ed). ,N ew York : Pantheon Books

6 Taylor, Rae and Erin L. Nabors. 2009. Pink or Blue... Black and Blue? Examining Pregnancy as a Predictor of Intimate Partner Violence and Femicide. Violence A gainst Women, Vol. 15, No. 11, 1273-1293

7 Brown, H. Douglas. 2000. Principles of Language Learning and Teaching. New York : Addison Wesley Longman, Inc.

$8 \quad$ Khairuddin. 1998. Pelecehan Seksual Terhadap Istri. Yogyakarta: PPK UGM

9 La Side. 1977. Beberapa Keterangan dan Petunjuk Tentang Pengertian dan Perkembangan-Siri dalam Suku Bugis. Ujung Pandang: Institute Research, Hasanuddin University

10 Rahim, Rahman., 1985. N ilai-N ilai U tama Kebudayaan Bugis. Ujung Pandang: Lembaga Penelitian Universitas Hasanuddin. 
11 Ashari. 2007, Perempuan Dan Religi Patuntung: Studi tentang Ajaran Pasang ri Kajang pada Komunitas Ammatoa Kajang, Sulawesi Selatan. Disertasi Surabaya: Pasca Sarjana Universitas Airlangga. hal. 20

12 HeiseL., op.cit

13 Khairuddin, op.cit

\section{DAFTAR PUSTAKA}

Ashari. 2007. Perempuan Dan Religi Patuntung: Studi tentang Ajaran Pasang ri Kajang pada Komunitas Ammatoa Kajang, Sulawesi Selatan, D isertasi. Surabaya: Pasca Sarjana Universitas Airlangga.

Cury, MA., Perrin N and Wall E., 1998. Effects of Abuse on Maternal Complications and Birth Weight in Adult and Adolescent Women. International Journal of O bstertics and Gynecology, Vol. 92 Pp 530-534

Brown, H. Douglas. 2000. Principles of Language Learning and Teaching. New York: Addison Wesley Longman. Inc.

Foucault, Michel. 1980. Power/Knowledge: Selected Interview \& Other W riting 19721977. Colin Gordon (ed) New York: Pantheon Books

Gazmararian, J.A., Lazorick, S., Splitz, A.M., Ballard, T.J., Saltzman, L.E., \& Marks, J.S., 1996. Prevalence of Violence against Pregnant Women. Journal of A merican M edical A ssociation, 275, 1915- 1920.

Heise L. 1998. Violence Against Women. an integrated Ecological framework in Stanley G. French, Wanda Teays dan Laura M.Purdy (eds). Violence Against Women; Philosophical Perspective. Ithaca: Cornell University Press. pp. 262-290

Khairuddin. 1998. Pelecehan Seksual Terhadap Istri. Yogyakarta: PPK UGM

La Side. 1977. Beberapa Keterangan dan Petunjuk Tentang Pengertian dan Perkembangan-Siri dalam Suku Bugis. Ujung Pandang: Institute Research. Hasanuddin University.

Rahim, Rahman., 1985. Nilai-Nilai Utama Kebudayaan Bugis. Ujung Pandang: Lembaga Penelitian Universitas Hasanuddin.

Taylor, Rae and Erin L. N abors. 2009. Pink or Blue... Black and Blue? Examining Pregnancy as a Predictor of Intimate Partner Violence and Femicide. Violence A gainst W omen, Vol. 15. N o. 11. 1273-1293. 
